\title{
Pellet Production from Woody and Non-Woody Feedstocks: A Review on Biomass Quality Evaluation
}

\author{
Rodolfo Picchio ${ }^{1, *(\mathbb{D}}$, Francesco Latterini ${ }^{2}\left(\mathbb{D}\right.$, Rachele Venanzi ${ }^{1}$, Walter Stefanoni ${ }^{2}(\mathbb{D}$, \\ Alessandro Suardi ${ }^{2}$ (D), Damiano Tocci ${ }^{1}$ and Luigi Pari ${ }^{2}$ (D) \\ 1 Department of Agricultural and Forest Sciences (DAFNE), Tuscia University, 01100 Viterbo, Italy; \\ venanzi@unitus.it (R.V.); toccidamiano91@gmail.com (D.T.) \\ 2 CREA Research Centre for Engineering and Agro-Food Processing, Via della Pascolare, 16, \\ 00015 Monterotondo (Rome), Italy; francesco.latterini@crea.gov.it (F.L.); walter.stefanoni@crea.gov.it (W.S.); \\ alessandro.suardi@crea.gov.it (A.S.); luigi.pari@crea.gov.it (L.P.) \\ * Correspondence: r.picchio@unitus.it; Tel.: +39-0761-357-400
}

Received: 17 April 2020; Accepted: 1 June 2020; Published: 8 June 2020

\begin{abstract}
Forest and agricultural biomass are important sources of renewable and sustainable fuel for energy production. Their increasing consumption is mainly related to the increase in global energy demand and fossil fuel prices but also to the limited availability of petroleum and the lower environmental impact of these biomass compared with other non-renewable fuels. In particular, the pellet sector has seen important developments in terms of both production and the number of installed transformation plants. In addition, pellet production from non-woody biomass is increasing in importance. One of the fundamental aspects for the correct and sustainable use of a biofuel is evaluation of its quality. This is even more important when dealing with pellet production, considering the broad spectrum of possible raw materials for pelletizing. Considering the significant number of papers dealing with pellet quality evaluation and improvement in the last decade, this review aims to give the reader an overall view of the most current knowledge about this large and interesting topic. We focused on pellets of agricultural and forestry origin and analyzed papers regarding the specific topic of pellet quality evaluation and improvement from the last five years (2016-2020). In particular, the review findings are presented in the following order: the influence of different agro-forest management systems on pellet quality; analysis of pellets from pure feedstocks (no blending or binders); the influence of blending and binders on pellet quality; and the influence of pre and post treatments. Finally, a brief discussion about actual research lacks in this topic and the possibilities for future research are presented. It is important to underline that the present review is focused on the influence of the biomass characteristics on pellet quality. The effects of the process parameters (die temperature, applied pressure, holding time) on pellet features are not considered in this review, because that is another very large topic deserving a dedicated paper.
\end{abstract}

Keywords: woody pellet; agropellet; quality; standards; blending

\section{Introduction}

The constant decreasing availability of fossil fuels as energy sources and the huge environmental problems related to their use, have led to great interest in renewable energy sources [1]. One of these interesting sources is undoubtedly biomass. The main problems related to the use of biomass for energy production are linked to its irregular shape, low bulk density, and high moisture content which create difficulties in handling, transport, and storage [2-6]. A recent trend to remedy the critical issues in the use of biomass for energy purposes is densification and standardization to exploit a homogeneous and easy-to-use solid biofuel, which is also characterized by a higher energy density [7]. Currently, 
there are various densification processes available, but the most commonly used is that of pelletization. Biomass use in form of pellets generates a biofuel that is more cost-effective than the direct use of non-modified biomass residues for energy production. This process, called extrusion, consists of applying high pressure and high temperatures to semi-dry biomass pre-processed in dust, sawdust or shavings, passing it through a hole of a few millimeters in size, and producing small cylinders that are cut to the desired length and then cooled [8]. This process increases the bulk density of biomass, thus reducing handling, transport, and storage costs [9-13]. The great importance of the pelletization process for energy production is highlighted by the data from a 2019 statistical report on pellets [14], which underlines the increasing amount of pellet production worldwide (Figure 1).

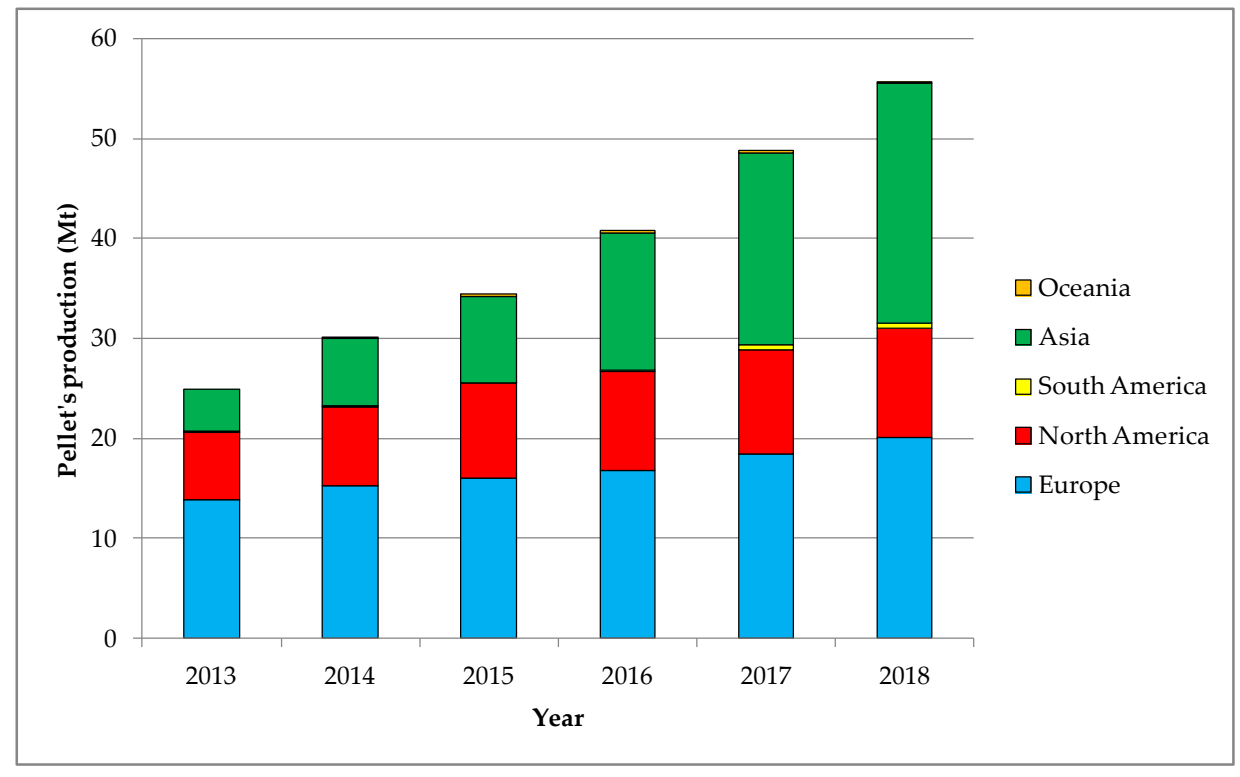

Figure 1. Worldwide pellet production from 2013 to 2018 [14].

One of the fundamental aspects for the correct and sustainable use of a biofuel is the evaluation of its quality. Pellet quality is affected by multiple parameters linked to both the properties of the raw material used, for example, particle size distribution, moisture content, and chemical composition, and to the operating conditions, like the die temperature, applied pressure, and holding time [15-17]. In addition, pellets can be produced from various feedstocks, mainly related to agricultural and forest activities [18-21]. Considering the broad spectrum of possible raw materials for pelletizing, quality evaluation of pellets is even more important.

In particular, of the many types of biomass, wood represents the main feedstock for pellet production [21]. Sawdust is an ideal substrate, as it is untreated and even minor contaminants are removed through bark removal and washing of saw logs prior to sawing [8]. However, considering the increasing demand for wood pellets and the limited supply of sawmill residue, there has been growing interest and exploration in the production of pellets from other processes and sources [22]. Recently, pellets produced from forest logging residue or dedicated agroforestry plantations have been used [23].

Non-woody biomass, like agricultural residue, is one of the most important alternative feedstocks for pelletization [8]. This kind of biomass could be of significant use thanks to the large amount available, the low price, and the importance of agricultural waste re-use as by-products in maintaining a green and circular economy [24]. However, in most cases, the quality of agropellets is less than that of forest pellets, and the main disadvantages are related to the low bulk density, high ash content, and low calorific value [25]. One possible solution is mixing woody and non-woody biomass. In fact, using various blends generally leads to an increase in pellet quality [10]. 
Moreover, in recent years, several studies have focused on improving the pellet quality, in particular regarding durability and bulk density, through the use of organic components, for example, sewage sludge and inorganic binders [26-28].

Another solution to improve the quality is pre-treatment of the feedstock or post-treatment of the pellet. The main aim of pre-treatment is the structural change in biomass feedstock to make it more suitable for pelletization. The two most well-known pre-treatments are steam explosion treatment and torrefaction [29]. Steam pre-treatment, also known as autohydrolysis or steam explosion, consists of exposing feedstock, firstly, to steam (typically at $140-260{ }^{\circ} \mathrm{C}$ ) and then, suddenly, to atmospheric pressure [29]. The first step leads to the hydrolysis of hemicellulose and to the activation of lignin, while the second phase (pressure drop) causes biomass fragmentation [30,31]. This type of treatment has been found to be particularly effective for agricultural residue and hardwood [32]. The main aim of steam explosion is to increase mechanical strength due to the activation of inherent lignin [29]. On the other hand, torrefaction is a thermochemical treatment which can be applied to both the feedstock (pre-treatment) and to the already formed pellet (post-treatment) [29]. This type of treatment is performed in an anoxic environment or under a very low oxygen content $\left(<6 \mathrm{vol} \% \mathrm{O}_{2}\right)$ in a temperature range of between 200 and $300{ }^{\circ} \mathrm{C}[33,34]$. When applied to the feedstock, this process results, generally, in more grindable material with a higher energy density, increased homogeneity, a higher thermal stability, and greater hydrophobicity [29]. The main problem linked with feedstock torrefaction is the high friction in the die channel which causes an increase in energy consumption during pellet formation [35]. Moreover, pelletization of torrefied biomass is more difficult and the correct formation of pellets is not always achieved [36]. In order to avoid these criticalities, this process is also used as a post-treatment with the aim of increasing the heating value and hydrophobicity of the pellet [29].

Considering the significant number of papers dealing with pellet quality evaluation and improvement in the last decade, this review aims to give to the reader an overall view of the most current knowledge on this large and interesting topic. We focused on pellets of agricultural and forestry origin and analyzed papers from the last five years (2016-2020) that investigated the specific topic of pellet quality evaluation and improvement.

First, the methodology used to construct the review is given. Then, an overview of the pellet quality standards classification is reported. After this, the review findings are presented and commented in the following order: influence on pellet quality of different agro-forest management systems; analysis of pellets from pure feedstocks (no blending or binders); the influence of blending and binders on pellet quality; and the influence of pre and post treatments. Finally, some ideas for future research directions were shown and some conclusions were formulated.

It is important to underline that the present review is focused on the influence of the biomass characteristics on pellet quality. The effects of the process parameters (die temperature, applied pressure, holding time) on pellet features are not considered in this review, because that is another very large topic which deserves a dedicated review.

\section{Materials and Methods}

This bibliographical search was developed using Boolean operators and implementing a symbolic logic system that creates relationships between concepts and words. The use of Boolean searching to carry out a systematic review allows one to analyze all studies in a specific research field [37]. Research was performed using the databases Scopus, ISI Web of Knowledge, and Google Scholar. The first keyword used was "pellet", limiting the research only to the "Energy" subject area. In this way 8364 findings were produced. Subsequently, the research was refined by limiting the findings only to the period 2016-2020. The number of findings decreased to 2323. Then, the keyword "quality" was used to further refine the papers. Consequently, the number of findings decreased to 626 .

After this, authors performed paper selection by reading the title and abstract of each article, and 71 articles were identified as suitable for the present review. A total of $43.66 \%$ of the analyzed papers dealt with the use of pure feedstock for pellet production; $21.13 \%$ were about the influence of 
blending on quality; $18.31 \%$ concerned the effect of binders; $15.49 \%$ dealt with pre- or post- treatment consequences; and only one paper $(1.41 \%)$ was about the influence of agrosystem management on pellet quality (Figure 2). Moreover, in Figure 2 an overview about the main topics of all papers dealing with pellet quality on Scopus repository is given to the reader. As it is possible to notice, there is a good balance among the percentage of papers dealing with forest biomass, agricultural residues, and both these are used as feedstock for pellet production.

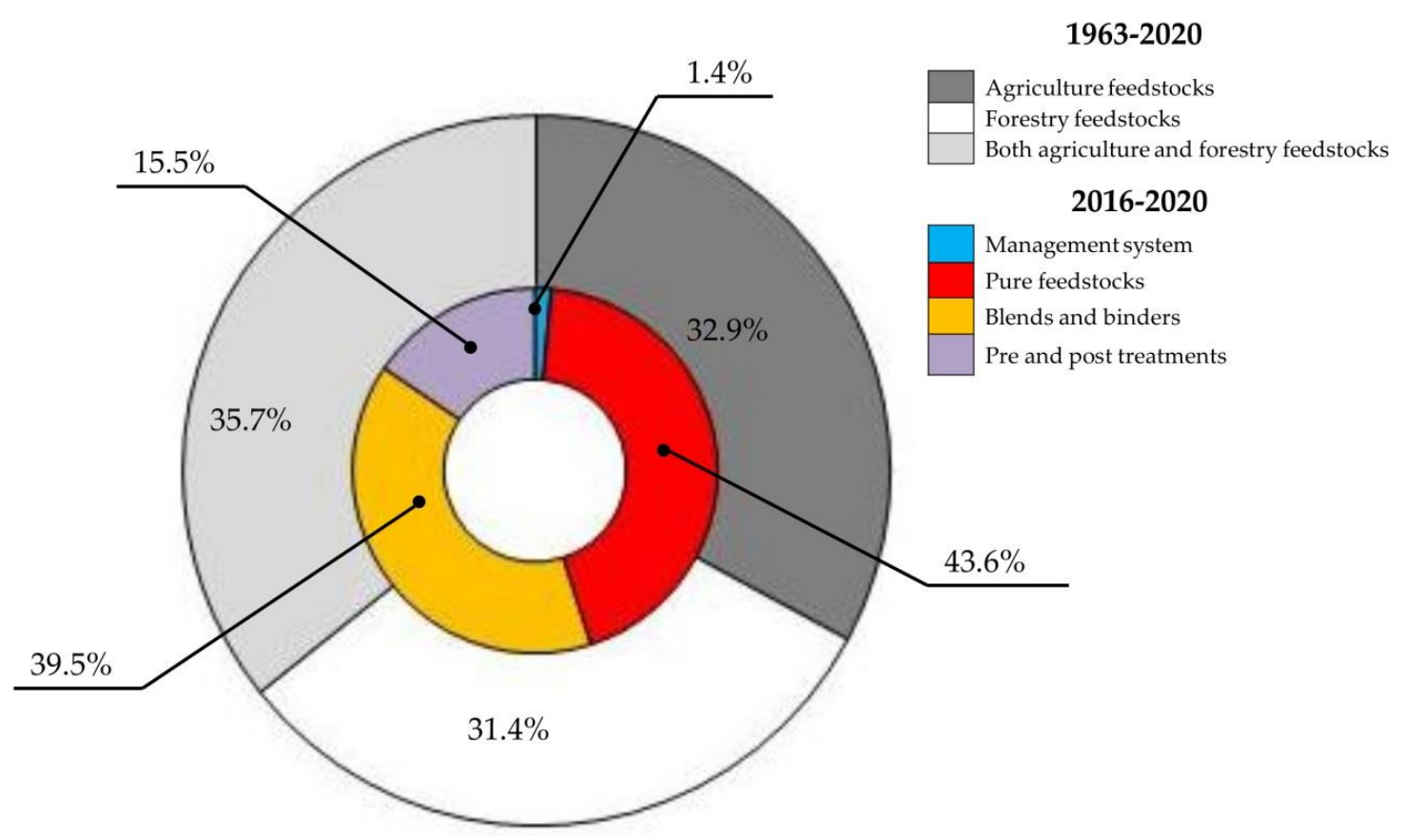

Figure 2. Percentages of the various identified main topics in relation to the total number of analyzed papers.

\section{Pellet Quality Standards}

International pellet quality standards were developed by the International Organization for Standardization (ISO). In particular, standards for the use of pellets as biofuel include EN ISO 17225-1 for general quality requirements, EN ISO 17225-2 for graded wood pellets for industrial and domestic use, and EN ISO 17225-6 for graded non-woody pellets. In the past, several European countries have developed regulations and standards for pellet quality certification, in particular, the Austrian standard ÖNORM M 7135, the Swedish standard SS 187120, the German standards DIN 51731 and DIN EN 15270, the Italian standard CTI-R04/05, and the French recommendation ITEBE [38].

ISO fuel specification standards (EN ISO 17225 series) were published in May 2014, and this series replaced EN 14961. National standardization bodies in Europe published the EN ISO 17225 series as a national standard at the end of November 2014 [39].

The graded wood pellet standard (EN ISO 17225-2) is related to the use of pellets for industrial and non-industrial use. Non-industrial use means fuel intended to be used in smaller appliances, such as in households and small commercial and public sector buildings [39]. According to this standard, the best quality class is A1, which represents virgin woods and chemically untreated wood residue that are low in ash and nitrogen. Pellets with a slightly higher ash content and nitrogen content are described as A2. Finally, there is property class B. This class includes chemically treated industrial wood by-products and residue [39]. Within ISO 17225-2, a classification of pellets for industrial use is also reported. This classification provides three different quality classes (I1, I2, and I3), which present slightly more restrictive requirements in comparison to classes A1, A2, and B for pellets for domestic use. The advent of this standard at European level represented an important step for the sector, 
ensuring greater transparency on a product along the full evolution and allowing greater uniformity with world markets.

Non-woody pellet standards (ISO 17225-6) relate to pellets made from blends and mixtures, including herbaceous, fruit, or aquatic biomass. This standard provides two classification tables, one for herbaceous and fruit biomass and blends and one for straw, miscanthus, and reed canary grass pellets. In general, non-woody pellets have high ash, chlorine, nitrogen, and sulfur contents [39] as well as a lower heating value (LHV). Consequently, their required standard is less restrictive, while considering the achievement of lower quality levels than wood pellets, in this sense, a greater attention would be desirable about clearly presenting qualitative differences and suggestions for use. Considering the high dynamism of this sector, it is important that standards for solid biofuels should be continuously under development. In particular, they should be quite strict especially in relation to the use of heterogeneous materials. For example, the US EPA (Environmental Protection Agency) imposed detailed restrictions on the type of fuels, including density, dimensions, inorganic fines $(\leq 1 \%)$, chlorides, ash content $(<2 \%)$, interdiction of demolition or construction waste, and trace metal concentrations less than $100 \mathrm{mg} / \mathrm{kg}$.

\section{Influence of Agro-Forest Management System on Pellet Quality}

The only paper that was found to deal with the influence of different management systems on pellet quality was that presented by Civitarese et al. [1]. In their study, a comparison of pellet quality was reported, taking into consideration three different ways of managing dedicated plantations for biomass production. In particular, the authors analyzed pellets from poplar plantations managed through short rotation forestry (SRF), medium rotation forestry with a six-year rotation period (MRF6), and medium rotation forestry with a nine-year rotation period (MRF9). The obtained results showed that all investigated categories presented a shortfall (in relation to ISO standards) regarding bulk density. The SRF pellets also showed problems with excessive ash content, and the durability of MRF9 was not sufficient to reach ISO quality standards. For the other investigated parameters, for example the lower heating value (LHV) or heavy metal content, all materials reached the A1 class standard according to EN ISO 17225-2. According to the authors' findings it seems that the best rotation cycle for poplar SRC with reference to pellet production is a 6 year period. Those with periods of three years indeed showed a major ash content, because of the higher percentage of bark, while 9 years material showed higher heavy metal content, moreover it is important to underline that such a long rotation period implies a more complex and specialized mechanization level for harvesting operation considering the high diameter of the stems to be cut. From the findings it is clear that the management system could influence pellet quality and consequently the energetic performance, for example: (i) pellet density increases char combustion time; (ii) pellets composed of bark had up to 50\% longer char combustion time. These performances could be directly linked to changes in extractives, ash, and lignin, characteristics that depend upon tree vigor class. Generally, low vigor trees have higher extractives, ash, and lignin contents than the vigorous trees.

\section{Pure Feedstock for Pellet Production}

Before showing the main findings about the characteristics of pellet produced from new feedstocks, it is necessary to give the reader a view of the characteristics of pellet made on existing and established feedstocks, i.e., hardwood tree species [40]. Such information is given in Table 1, in which characteristics of pellet from pine, spruce, and hemlock are reported. Moreover, in Table 1 the quality requirements for wood pellet for A1, A2 and B class are also shown. 
Table 1. Characteristics of pellet produced from pine, hemlock and spruce and ISO 17225-2 standards requirements for $\mathrm{A} 1, \mathrm{~A} 2$, and $\mathrm{B}$ classes.

\begin{tabular}{|c|c|c|c|c|c|c|c|c|c|}
\hline & $\begin{array}{c}\text { LHV MJ } \\
\mathrm{kg}^{-1}\end{array}$ & $\begin{array}{c}\text { Bulk } \\
\text { Density } \\
\left(\mathrm{kg} \mathrm{m}^{-3}\right)\end{array}$ & $\begin{array}{c}\text { Moisture } \\
(\%)\end{array}$ & $\begin{array}{c}\text { Durability } \\
(\%)\end{array}$ & $\begin{array}{c}\text { Ash Content } \\
(\%)\end{array}$ & N (\%) & $\mathrm{S}(\%)$ & $\mathrm{Cl}(\%)$ & Feedstock \\
\hline [41] & - & 603.00 & 8.50 & 98.50 & & & & & Pinus spp \\
\hline [42] & 18.50 & 709.00 & 9.60 & 97.80 & 0.70 & 0.06 & 0.02 & 0.01 & Pinus spp \\
\hline [43] & 18.13 & 540.90 & - & - & - & - & - & - & Pinus spp \\
\hline [44] & - & 680.00 & 8.86 & - & 0.78 & 1.43 & 0.02 & 0.02 & Pinus spp \\
\hline [45] & 16.90 & - & 7.30 & - & 1.30 & 0.50 & $<0.01$ & - & Pinus spp \\
\hline [46] & - & - & - & - & 0.10 & - & - & - & Picea spp \\
\hline [47] & 18.69 & 709.46 & 7.84 & 93.60 & 0.70 & 0.09 & $<0.01$ & $<0.01$ & Picea spp \\
\hline [47] & 18.28 & 756.23 & 5.79 & 96.80 & 0.35 & 0.07 & 0.01 & $<0.001$ & Tsuga spp \\
\hline $\begin{array}{c}\text { EN ISO } \\
17225-2 \text { A1 }\end{array}$ & $\geq 16.50$ & $\geq 600$ & $\leq 10.00$ & $\geq 97.50$ & $\leq 0.70$ & $\leq 0.30$ & $\leq 0.04$ & $\leq 0.02$ & \\
\hline $\begin{array}{c}\text { EN ISO } \\
17225-2 \text { A2 }\end{array}$ & $\geq 16.50$ & $\geq 600$ & $\leq 10.00$ & $\geq 97.50$ & $\leq 1.20$ & $\leq 0.50$ & $\leq 0.05$ & $\leq 0.02$ & \\
\hline $\begin{array}{c}\text { EN ISO } \\
17225-2 \text { B }\end{array}$ & $\geq 16.50$ & $\geq 600$ & $\leq 10.00$ & $\geq 96.50$ & $\leq 2.00$ & $\leq 1.00$ & $\leq 0.05$ & $\leq 0.03$ & \\
\hline
\end{tabular}

The production of forest residue pellets from the thinning of Mediterranean pine stands (Pinus halepensis Mill. and Pinus pinaster Aiton), which is generally an uneconomic intervention [48], generally showed a good quality according to ISO standards. In particular, the highest quality was shown for pellets from larger diameter logs and debarked ones, while pellets from branches showed a lower quality [49]. This aspect is linked to the higher percentage of bark present in branches which has negative influence on ash content.

Another interesting raw material for pellet production is beech (Fagus sylvatica L.) wood. Pellets produced from this species showed very good quality, reaching the A1 standard for most parameters and A2 for ash content [50]. This could be very interesting for the beech wood value chain, considering the large number of beech forests throughout Europe and taking into consideration that the possibilities of this forest-wood chain are currently not being completely exploited [51]. Obviously, economic evaluations are needed to put into practice what is written above.

The major problem for other types of forest residual biomass seemed to be an excessive ash content. Chestnut (Castanea sativa Mill.) pellets only reached the B class ISO standard [52], and the same was observed for birch (Betula spp) sawdust [53]. An even greater ash content was shown by willow (Salix spp), poplar (Populus spp), and scots pine (Pinus sylvestris L.) bark pellet [50].

In relation to the pellet quality from tropical wood species, Parra Artemio et al. [54] investigated pellet samples from Albizia amara Roxb., Ebenopsis ebano (Berland.) Barneby, and Havardia pallens Benth. The results were very interesting with good results for ash content, durability, and calorific value. However, other tests are needed to improve the knowledge on the pellet quality of tropical woody species considering the importance that the establishment of a pellet value chain could have for the economy of developing countries in such areas of the world.

Another interesting type of feedstock for pellet production could be shrub wood. This is mainly of interest for arid or semi-arid zones, where, after wildfire prevention interventions, there could be a consistent amount of biomass from shrubby species [55].

By focusing on pellet quality from shrubby biomass, it is possible to notice the generally good quality in terms of bulk density, durability, and LHV. Instead, the main problems are linked to the excessive or consistent ash content as well as excess sulfur and chlorine concentrations [52,55]. The best pellet quality was shown by Rhododendron ponticum L. and Genista cinerascens L. [52,55]. Additionally, in this case, the major cause of the high ash content is probably linked to the high percentage of bark present in such species as a consequence of low stem diameter. A possible solution to using such feedstock for pellet production, thus evaluating a raw material whose disposal after forest restoration intervention is actually a cost, could be a certain percentage of blending with softwood sawdust in order to reduce the ash content.

The analysis of pellets from energy crops indicated a generally good quality in relation to the ISO standard for agropellets. Aragon-Garita [56] investigated the quality of various energy crops 
in Costa Rica, in particular Gynerium sagittatum Aubl., Phyllostachys aurea Riviere, Arundo donax L., Pennisetum purpureum Schumach, and Sorghum bicolor L. All pellets reached the requirements of the quality standard for LHV and almost every type, except Arundo donax L., also showed good quality in terms of ash content. However, Pennisetum purpureum Schumach and Sorghum bicolor L. contained excessive moisture content. The aspect of excessive moisture is a key issue for herbaceous energy crops management and the possible solutions are, on the one hand, a well-planned supply chain which ensures a drying period in optimal conditions, thus avoiding dry matter losses, and on the other hand the usage of harvesting systems which allow simpler on-field drying, for example mower-conditioners or dedicated headers. Another study highlighted the reasonably good performance of the Reed Canary Grass (Phalaris arundinacea L.) pellet, which reached an overall quality class of B according to ISO 17225-6 [50]. Finally, the Jatropha curcas L. pellet showed good results concerning bulk density and LHV but had a slightly excessive amount of moisture [57,58]. However, deeper investigation is needed to assess the overall feasibility of using this feedstock for pellet production.

Considering the pellet quality from agricultural residue feedstock, the first thing that can be observed is that it represents the topic of the majority of the investigated papers. This shows the great importance given by scientific research to the issue of agricultural residue valorization through densification and use as biofuels [59-62].

One of the most frequently investigated feedstocks is rice (Oryza spp.) cultivation residue [63], particularly straw, husk, and chaff. Yang et al. [64] analyzed pellets from straw and husks and detected excess chlorine in both types as well as excessive ash in the rice husk pellet. The same problems of an excessive ash content, together with low durability and low LHV, were detected for rice husk pellets by Rios-Badran et al. [65]. Regarding rice chaff, problems related to durability and an excess chlorine content were shown [66].

Corn (Zea mays L.) residue is another feasible feedstock for pellet production. Analysis conducted in the last five years showed a generally good quality for the pellets produced from corn cobs (obviously considering agropellet standards as a reference) but with slightly conflicting evidence. In fact, Djatkov [67] showed good quality in terms of durability and mechanical resistance parameters, while Miranda [68] highlighted the presence of excess chlorine and a low durability. Corn stover seems to be a feedstock with lower potential [67].

As a general comment to the reported above issue of pellets production from agricultural residues, it is important to underline that it is probably almost impossible to improve the quality of pellet produced from such feedstocks "as is" because of the intrinsic characteristics of these materials. On the other hand, it is fundamental to value these residues considering the large amount of them and the need for renewable energy production. Pelletization represents a valid solution to reach this aim, since one of the main problems related to residues is the low bulk density. Scientific efforts are needed in order to develop plants able to face the main flaws of such kinds of pellet also in the long run. Another possible solution is, even in this case, blending with materials with higher lignin content such as coniferous wood. Finally, a key issue could be developing and/or give major space to technologies able to produce pellet directly on field, in order to further lower supply chain costs.

Some commonly investigated feedstocks in the reference period (2016-2020) that did not perform well are oil palm (Elaeis spp.) residues, such empty fruit bunches, fruit mesocarps, leaves, and fronds. All of these feedstocks showed problems linked with their ash content, durability, bulk density, and LHV $[25,69,70]$.

Coffee residue (spent coffee grounds and coffee husks) could be another possible suitable material for pelletization, but more studies of this feedstock are needed. Jeguirim et al. [71] analyzed spent coffee ground and coffee husk pellets, finding that they were high quality in terms of moisture, ash content, and LHV. However, Park et al. [66] reported a consistent lack in quality regarding the bulk density, durability, chlorine content, and copper content of spent coffee ground pellets. These controversial results claim for further scientific investigation on this field, in order to better define the possibility of using this important residue for energy production. 
Pelletization of another important agriculture residue, biomass from pruning operations, was investigated by several authors in the reference period (2016-2020). The main problems with this type of biomass, in particular for olive grove and vineyard pruning, are its excessive ash content and, most of all, its excessive copper content, which is probably linked to the use of phytosanitary treatments with copper-based products [72,73]. Apple pruning seems, instead, to be a better material for pelletization, with an ash content and LHV that met the ISO standards; however, problems linked to a low bulk density have been detected [74]. Regarding the issue of pellet production from pruning residues, a key aspect to be further investigated is the economical sustainability of the supply chain, considering that pruning collection represents a certain cost by itself $[75,76]$, also in this case an interesting solution could be the development of mobile technologies for pellets production at the farm, thus limiting supply chain costs [73].

Finally, many papers published in the last 5 years have focused on the use of other alternative residual biomass for pelletization. In order to give the reader a comprehensive view of these, Table 2 shows the main positive and negative aspects of each of these alternative feedstocks.

Table 2. Main postive and negative aspects found in the literature for relatively new feedstocks for pellet production.

\begin{tabular}{cccc}
\hline Feedstock & Reference & Positive Aspects & Negative Aspects \\
\hline Wheat straw & {$[50]$} & $\begin{array}{c}\text { Lower Heating Value (LHV), ash, all } \\
\text { chemical parameters except for chlorine }\end{array}$ & Chlorine \\
Scenedesmus microalgae & {$[68]$} & Durability and LHV & Ash, Nitrogen, Chlorine \\
Garden waste & {$[77]$} & LHV & Ash, Moisture \\
Soybean & {$[78]$} & - & Ash, LHV (very important shortfall) \\
Sugarcane bagasse & {$[78]$} & - & Ash, LHV (very important shortfall) \\
Cherry stones & {$[79]$} & LHV, all chemical parameters & Bulk density \\
Fallen leaves & {$[80]$} & Durability & Bulk density, LHV \\
Chamomile wastes & {$[53]$} & LHV, and Ash (mostly LHV) & Bulk density \\
\hline
\end{tabular}

As it is possible to see in Table 2, the main problems for the majority of these materials are their ash content (microalgae, garden wastes, soybean, sugarcane bagasse) and bulk density (cherry stones, fallen leaves and chamomile wastes); however, some of them also show a shortfall related to their LHV (soybean, sugarcane bagasse, fallen leaves) and chlorine content (wheat straw, microalgae).

Regarding feedstocks that present shortfalls related to physicochemical variables, for example, LHV or ash content, it is difficult to improve these negative aspects without using binders, blending, or pre-/post-treatments. In contrast, for feedstocks that are lacking in quality in relation to ISO standards in terms of mechanical characteristics, it could be possible to improve these aspects by enhancing the pelletization process, for example, by applying major pressure or a different temperature. Therefore, it could be interesting to produce cherry stone pellets or chamomile waste under different pelletization conditions and test whether the bulk density of the obtained material meets the quality standards.

It is interesting to note that considering raw materials mainly as "watertight compartments", and analyzing in detail their energetic characteristics, was the first step in the production of high-quality pellets. Initially, blending these raw materials for the production of high-quality pellets was a topic overlooked by researchers and more developed at a technical and commercial level. Current research developments in the sector allowed integrated analyzes aimed at the production of high-quality pellets. The data presented in the next chapter show the important results reached transferring the results of pure research to technical applications.

\section{Effects of Blending and Binders on Pellet Quality}

One of the possible solutions to improve pellet quality is co-pelletization, i.e., blending two or more feedstocks. The general trend is to use woody materials, for example sawdust, to improve the overall quality of pellets from alternative feedstocks [29]. An increase in the lignin content of wood is 
associated with an improvement in pellet quality, mostly regarding the heating value, bulk density, durability, and ash content $[29,81]$.

In recent years, co-pelletizing has been one of the most commonly investigated methods. Mixing reed canary grass, timothy hay (Phleum pratense L.), and switchgrass (Panicum virgatum L.) with pine and spruce sawdust resulted in good quality pellets. In particular, an increase in LHV and reduced ash, chlorine, and nitrogen contents were detected in comparison to pure herbaceous feedstocks which also required only $2 \mathrm{~kJ}$ of energy for the pelletization almost as low as woody biomass [82]. Mixture of pine and spruce sawdust with bamboo improved the ash content (lower than $8 \%$ ) and bulk density which increased from 0.54 to $0.60 \mathrm{~g} \cdot \mathrm{cm}^{-3}$ despite the slight reduction in LHV [83]. Regarding blending ratios, the addition of $30 \%-40 \%$ pine or spruce sawdust consistently improved wheat straw and maize pellets [10,72].

Higher proportions of pine sawdust are necessary for other feedstocks. Garcia et al. [84] mixed pine sawdust with many agricultural alternative raw materials and evaluated the quality of the obtained pellet according to ISO standards for industrial pellets. Blends of pine sawdust with almond shell and olive stone contents of up to $30 \mathrm{wt} \%$, as well as a pine cone leaf content of up to $15 \mathrm{wt} \%$ produced I1 pellets. Blends of pine sawdust with coffee dregs, coffee husks, and grape pomace proportions of up to $10 \mathrm{wt} \%$; blends with hazelnut shell, miscanthus, pine kernel shell, and switchgrass contents of up to $15 \mathrm{wt} \%$; and blends with a pine cone leaf content of between 15 and $30 \mathrm{wt} \%$ generated I3 class pellets. Classification was not possible for cocoa shells mixed with pine sawdust due to the low bulk density of the pellets [84].

In addition to coniferous species, birch, osier, and alder wood showed good performances following blending; specifically, they were mixed with reed canary grass to improve the LHV of the produced pellet [85]. Less satisfactory results were reported for aspen wood [85].

Olive pruning residual biomass is another woody material that was shown to be feasible for the improvement of pellet quality. Mixing pruning residues with $25 \%$ stage 2 olive pomace and $50 \%$ stage 3 olive pomace produced a good quality pellet. In particular, a consistent increase in durability and a lower ash content (up to $2.4 \%$ ) were shown in comparison with pellets from pure olive pomace although the extremely high values of ash-forming elements such as $\mathrm{Fe}, \mathrm{Mg}$, and $\mathrm{K}$ [86].

Interesting findings were reported by Hosseinizad et al. [87] and Cui et al. [88] regarding the blending of woody biomass with Chlorella spp. microalgae. Mixing microalgae with sawdust resulted in a consistently lower energy requirement for the pelletization process and a substantial increase in the mechanical characteristics of pellets.

Regarding non-woody blends, recent scientific findings have reported a generally low efficiency in comparison to woody-non-woody blends. Wang et al. [89] reported an increase only in mechanical characteristics by mixing wheat and rice straw, while the LHV did not improve substantially. Similar results were presented by Lisowski et al. [90] in relation to hay and straw mixing-a mechanical improvement without positive effects on LHV.

Binders are organic or inorganic substances that can be added, generally in a lower quantity, to feedstock for pelletization, in order to improve the mechanical characteristics of the pellet. In addition, binders can reduce the energy required for pelletization.

Sewage sludge is a possible binder, and scientific evidence has been reported regarding its capacity to improve the mechanical characteristics of pellets but, on the other hand, it increases the ash content from $4.28 \%$ to $13.01 \%$ when the fir-sludge ratio shifts from 25 to $50 \mathrm{wt} \%$ [91]. At the same straw-sludge ratios, the residues increase from 15.86 to $20.04 \mathrm{wt} \%$.

Abedi et al. [92,93] used lignin and proline as binders for oat (Avena sativa L.) pellets and showed a positive effect on the LHV but a slightly negative effect on the ash content. The use of oat hull as cobinder at the concentrations of $10 \%$ and $50 \%$, increases the HHV of sawdust pellet by $0.8 \mathrm{MJ} / \mathrm{kg}$ [ 93 ].

Another interesting bio-oil for pelletization is apple tree pyrolysis, which has been shown to improve the hydrophobicity of pellets. In fact, moisture content varied from $0 \%$ to $4.74 \%$ in 30 hours test [94]. 
Potato starch is another common binder that can reduce the energy needed for pellet formation; on the other hand, it increases the moisture content and substantially decreases the LHV $[95,96]$. Concentrations of $10 \%, 20 \%$, and $30 \%$ provided ash content of $1.45 \%, 1.50 \%$, and $1.59 \%$ and calorific value of $18.2,18.1$, and $18.0 \mathrm{MJ} \mathrm{kg}^{-1}$, respectively.

The effects of paraffin, corn starch, and dolomite on the quality of wheat straw pellets were investigated by Gageanu et al. $[97,98]$. They found beneficial effects of these binders on the pellet length, surface, and shape. These additives were also beneficial for decreasing the moisture content. The bulk density significantly increased for samples obtained using additives. LHV registered a small decrease when paraffin and corn starch were used as additives to wheat straw pellets. The ash content was also positively influenced by using additives.

Other binders which have been shown to increase the mechanical characteristics of pellets are sugar beet molasses [99], Persea kurzii kosterm powder [100], carboxymethyl cellulose [101], calcium carbonate [102], and cow dung [103]. Cashew nut shell decreases the mechanical characteristics but increases the LHV of pellet of approximately 1 and $0.5 \mathrm{cal} \cdot \mathrm{g}^{-1}$ in comparison with the use of Persea and dammar as binders, respectively. On the other hand, the use of cashew nut shells causes the production of unpleasant smoke and tar deposits [100].

Gerhig et al. [104] tested the use of kaolin to improve the quality of pellets from willow using short rotation coppices. Kaolin did not have a positive influence on the LHV or the ash content. Conflicting results were reported for chemical characteristics with decreases in sulfur and chlorine but substantial increases in $\mathrm{Al}$ and $\mathrm{Pb}$. Moreover, $\mathrm{CO}$ emissions decreased, but $\mathrm{SO}_{2}$ emissions were significant.

Finally, Cheng et al. [27] analyzed the use of coal tar (CTR) as binder. They reported a better mechanical resistance and an increased LHV of 19.32, 21.35 and $21.00 \mathrm{MJ} \mathrm{kg}^{-1}$ in wheat straw pellets, sawdust pellets and moso bamboo pellets, respectively, when $35 \mathrm{wt} \%$ CTR was applied. At the same concentration, also LHV of lignite pellets increased from 13.52 (without CTR) to $18.61 \mathrm{MJ} \cdot \mathrm{kg}^{-1}$.

Obviously, a proximate analysis is needed for a deeper evaluation of this binder.

An overall summary on the literature findings about the effects of blending or binders on pellet quality is given in Table 3 .

From Table 3, it is possible to see that the majority $(71.9 \%)$ of analyses conducted in the last years focused on only four variables (LHV, ash content, bulk density, and durability). Table 3 also reveals that either blending or binder addition led to an increase in mechanical characteristics in all cases. However, the results regarding the improvement of ash content and, particularly, LHV were not always positive.

Finally, it is necessary to give some information about the impact of blending and binding processes on pellets production costs. As found by Garcia [105] adding 20\% glycerol to torrefied pine pellet increased production cost from 142.50 to 237 EUR $^{-1}$. However, a decrease of $10 \%-20 \%$ of storage and transport costs was detected, and this aspect is very interesting mostly for industrial use of pellet [105]. On the other hand natural blending of wooden biomass and agricultural residues seems to be a solution with lower costs, in particular a mixture of 50\% maize residues and $50 \%$ Pinus radiata sawdust showed $42.8 \%$ lower production costs than pure pine pellet [72]. The research has reached a high degree of improvement but now it will be necessary, in the qualification of the pellet, to consider also parameters related to the sustainability of production, the only real way to evaluate management systems, feedstock, and treatments in an integrated way. 
Table 3. Overall summary of the effect of blending or binders on pellet quality. Green cue balls indicate a positive effect of the blending/binder on the variable, red cue balls indicate a negative effect on the variable, and white cue balls represent that the variable was not investigated in the study or that no effect was found by the authors. LHV: lower heating value; BD: bulk density; Dur: durability; Ash: ash content; RE: energy required for pelletization; Hyd: hydrophobicity; Moi: moisture. "Analysis \%" represents the ratio between the number of papers that analyzed variable " $x$ " and the total number of analyses conducted on all variables in every investigated paper. "Success \%" represents the ratio between the number of papers that showed a good effect of the blend/binder on variable " $x$ " and the total number of papers that analyzed variable " $x$ ".

\begin{tabular}{|c|c|c|c|c|c|c|c|c|c|c|c|c|c|c|c|c|}
\hline \multirow[t]{2}{*}{ Reference } & \multicolumn{2}{|c|}{ Treatment } & \multirow[t]{2}{*}{ LHV } & \multirow[t]{2}{*}{ BD } & \multirow[t]{2}{*}{ Dur } & \multirow[t]{2}{*}{ Ash } & \multirow[t]{2}{*}{ RE } & \multirow[t]{2}{*}{ Hyd } & \multirow[t]{2}{*}{ Moi } & \multirow[t]{2}{*}{$\mathrm{Cl}$} & \multirow[t]{2}{*}{$\mathbf{N}$} & \multirow[t]{2}{*}{$S$} & \multirow[t]{2}{*}{ Al } & \multirow[t]{2}{*}{$\mathbf{P b}$} & \multirow[t]{2}{*}{$\mathrm{CO}$} & \multirow[t]{2}{*}{$\mathrm{SO}_{2}$} \\
\hline & Blending & Binding & & & & & & & & & & & & & & \\
\hline [27] & & $x$ & $\bullet$ & • & $\bullet$ & 0 & 0 & 0 & 0 & 0 & 0 & 0 & 0 & 0 & 0 & 0 \\
\hline [82] & $x$ & & $\bullet$ & 0 & 0 & $\bullet$ & $\bullet$ & 0 & 0 & $\bullet$ & $\bullet$ & 0 & 0 & 0 & 0 & 0 \\
\hline [83] & $x$ & & $\bullet$ & $\bullet$ & 0 & $\bullet$ & 0 & 0 & 0 & $\bigcirc$ & 0 & 0 & 0 & 0 & 0 & 0 \\
\hline [85] & $x$ & & $\bullet$ & 0 & 0 & $\bullet$ & 0 & 0 & 0 & $\bullet$ & 0 & 0 & 0 & 0 & 0 & 0 \\
\hline [86] & $x$ & & 0 & 0 & $\bullet$ & $\bullet$ & $\bigcirc$ & 0 & 0 & 0 & 0 & 0 & 0 & 0 & 0 & 0 \\
\hline [87] & $x$ & & 0 & $\bullet$ & - & 0 & $\bullet$ & 0 & 0 & 0 & 0 & 0 & 0 & 0 & 0 & 0 \\
\hline [88] & & $x$ & 0 & • & - & 0 & - & 0 & 0 & 0 & 0 & 0 & 0 & 0 & 0 & 0 \\
\hline [89] & $x$ & & $\bullet$ & $\bullet$ & $\bullet$ & 0 & 0 & 0 & 0 & 0 & 0 & 0 & 0 & 0 & 0 & 0 \\
\hline [90] & & $x$ & $\bullet$ & $\bullet$ & $\bullet$ & 0 & 0 & 0 & 0 & 0 & 0 & 0 & 0 & 0 & 0 & 0 \\
\hline [91] & $x$ & & 0 & - & - & $\bullet$ & 0 & 0 & 0 & 0 & 0 & 0 & 0 & 0 & 0 & 0 \\
\hline [92] & $x$ & & $\bullet$ & 0 & 0 & • & 0 & 0 & 0 & 0 & 0 & 0 & 0 & 0 & 0 & 0 \\
\hline [93] & $x$ & & • & 0 & 0 & • & 0 & 0 & 0 & 0 & 0 & 0 & 0 & 0 & 0 & 0 \\
\hline [94] & & $x$ & 0 & 0 & 0 & 0 & 0 & - & 0 & 0 & 0 & 0 & 0 & 0 & 0 & 0 \\
\hline [95] & $x$ & & $\bullet$ & 0 & 0 & 0 & • & 0 & $\bullet$ & 0 & 0 & 0 & 0 & 0 & 0 & 0 \\
\hline [96] & & $x$ & $\bullet$ & 0 & 0 & 0 & • & 0 & $\bullet$ & 0 & 0 & 0 & 0 & 0 & 0 & 0 \\
\hline [97] & & $x$ & $\bullet$ & • & 0 & • & 0 & 0 & • & 0 & 0 & 0 & 0 & 0 & 0 & 0 \\
\hline [98] & & $x$ & • & • & 0 & - & 0 & 0 & • & 0 & 0 & 0 & 0 & 0 & 0 & 0 \\
\hline [99] & & $x$ & 0 & • & 0 & 0 & 0 & 0 & 0 & 0 & 0 & 0 & 0 & 0 & 0 & 0 \\
\hline [100] & & $x$ & 0 & • & $\bullet$ & 0 & 0 & 0 & 0 & 0 & 0 & 0 & 0 & 0 & 0 & 0 \\
\hline [101] & & $x$ & 0 & • & • & 0 & 0 & 0 & 0 & 0 & 0 & 0 & 0 & 0 & 0 & 0 \\
\hline [102] & & $x$ & 0 & • & - & 0 & 0 & 0 & 0 & 0 & 0 & 0 & 0 & 0 & 0 & 0 \\
\hline [103] & & $x$ & 0 & • & • & 0 & 0 & 0 & 0 & 0 & 0 & 0 & 0 & 0 & 0 & 0 \\
\hline [104] & $x$ & & $\bullet$ & 0 & 0 & $\bullet$ & 0 & 0 & 0 & $\bullet$ & 0 & $\bullet$ & $\bullet$ & $\bullet$ & $\bullet$ & $\bullet$ \\
\hline Analysis \% & & & 19.4 & 20.9 & 16.4 & 14.9 & 7.5 & 1.5 & 6.0 & 4.5 & 1.5 & 1.5 & 1.5 & 1.5 & 1.5 & 1.5 \\
\hline Success \% & & & 30.8 & 100.0 & 100.0 & 60.0 & 100.0 & 100.0 & 50.0 & 100.0 & 100.0 & 100 & 0.0 & 0.0 & 100.0 & 0.0 \\
\hline
\end{tabular}

\section{Pre- and Post-Treatments}

The last section of the present review deals with the influences of pre- and post-treatments on the pellet quality. In this review, only one paper about steam explosion treatment influence was detected.

The mentioned above study analyzed, in detail, how steam treatment changes the biomass structure in order to determine the parameter with the biggest influence on pellet improvement [106]. The authors found that the structural changes caused by steam treatment, such as lignin relocation, hemicellulose hydrolysis, and size reduction, all aid in particle binding during pelletization. However, they have different contributions. In particular, the most important effect of steam treatment is lignin modification, while particle size distribution changes are not so important in improving the pelletization process and pellet quality [106]. About economic aspects of steam explosion treatment Pirraglia et al. [107] found an impact on overall production costs of $13 \%$.

Consistently, significant attention has been given to the torrefaction process, particularly as a pre-treatment. Feedstock torrefaction was very effective in improving pellet parameters, mostly those linked with energetic efficiency [108] but also mechanical characteristics $[109,110]$. Pellets produced from torrefied biomass were of a high quality according to ISO standards for industrial pellets when this treatment was applied to pruning residual biomass of olives and almonds. In particular, these pellets had an LHV that was 25\%-30\% higher than that of raw biomass and reached I1 or I 2 classes for size, moisture, bulk density, and heating value, but only obtained a classification of I3 for ash content [111].

This feedstock treatment was useful for improving the quality of pellets from blended material or from feedstock with the use of binders. Torrefied wood pine, with $20 \mathrm{wt} . \%$ glycerol and with $10 \mathrm{wt} . \%$ grape pomace and $10 \mathrm{wt} . \%$ glycerol met the quality standards for industrial pellet [105]. 
Less satisfactory results were shown in the reference period (2016-2020) for the use of torrefaction as a post-treatment. Manoucherijizad et al. [112] showed this post-treatment at a temperature range from 230 to $290^{\circ} \mathrm{C}$ improved the heating value and hydrophobicity of the torrefied wood pellets as compared with raw wood pellets. On the other hand, the hardness and durability of these pellets need to be improved to prevent dust formation during long-distance transport and safe storage operations.

Finally, it is important to notice that several recent studies focused on the issue of torrefaction process improvement. One possible solution is the use of ultrasonic vibration when pelletizing torrefied biomass. Song et al. [113] found that torrefied wheat straw biomass could be densified into good quality pellets with the assistance of ultrasonic vibration, whereas with the same pelleting pressure but without ultrasonic vibration, good pellets could barely be made.

Another useful way to improve the performance of this pre-treatment is to use "pressurized steam torrefaction". Kudo et al. [114] carried out the torrefaction of hardwood at $180-250{ }^{\circ} \mathrm{C}$ in the presence of saturated steam. This treatment considerably improved the pelletability of biomass, producing pellets with a tensile strength 5.2 times higher than that of the original biomass. This improvement in pelletability was comparable to that of wet torrefaction (process in compressed water). Meanwhile, pressurized steam torrefaction showed higher energy densification than wet process [114].

An interesting approach which was shown to be a feasible way to improve the quality of pellets produced from feedstocks affected by an excessive ash content is the combination of water leaching and torrefaction.

In 2019, Gong et al. [115] applied a first step of water leaching on empty fruit bunches from oil palm, rice straws, and sugarcane bagasse. Subsequently, torrefaction was performed at $200{ }^{\circ} \mathrm{C}$ for $5 \mathrm{~min}$. Leaching allowed the removal of the majority of ash and also practically reduced the chlorine and potassium concentrations. After this treatment, heating values increased by $4.42 \%$ in the empty fruit bunches, $4.68 \%$ in the rice straw, and $5.30 \%$ in the sugarcane bagasse [115].

The last method to improve the efficiency of this process, among those investigated by scientific research in the last five years, is the application of binders to biomass before torrefaction and pelletization. According to Rejdak et al. [116], a very good performance was shown when modified wheat starch was used as a binder, which resulted in improvements in the mechanical characteristics of torrefied pellets. The same author found that a blend of natural wheat starch, molasses, and sodium lignosulfonate resulted in a pellet with good efficiency with slightly lower mechanical characteristics in comparison to one produced with modified wheat starch [116].

Focusing on the economic assessment of the torrefaction process of densified biomass, literature findings reported that the torrefaction process increases the production cost by about $10 \%$. Pellet production costs indeed 47-64 EUR $\mathrm{t}^{-1}$ using sawdust as feedstock [117] and the price rises to 88-160 or 50-70 EUR $\mathrm{t}^{-1}$ starting from forest residues [118-121]; while prices for torrefied pellet production are in the range of 136-169 EUR t ${ }^{-1}$ [122-124]. On the other hand, it is important to underline that cost per energy unit of torrefied pellet can be lower than "normal" pellet's one. Indeed Yun et al. [125] reported a price ranging from 14.10 to $17.05 \mathrm{EUR} \mathrm{GJ}^{-1}$ for not treated pellet's production, while 11.87-13.71 EUR GJ ${ }^{-1}$ for torrefied pellet. In particular, the torrefied process with the best economic performance resulted to be torrefaction before grinding.

Considering what showed in this chapter, the two main (pre or post) treatments that currently seem to produce real quality improvements are the steam explosion system and torrefaction. Assessing the data reported in the cited researches, starting with the same qualitative characteristics of the pellet produced, in terms of sustainability, torrefaction is the most effective treatment. However, doubts remain about the real scale production chains that could be activated with these treatment methods and their efficacy and sustainability in comparison with traditional pelletization.

\section{Some Ideas for Future Research Directions}

When it comes to be consistent with a range of qualitative aspects related to pellet, the quality of starting material is crucial to the final characteristics of the product. Therefore, minimum standards of 
quality are strongly required in order to provide the market with a reliable product. Unfortunately, this threshold might not be met in future because of the ongoing changes in the field of renewable energy. In fact, according to the most recent regulations set by the European policy making (cit RED2), the contribution of agricultural residues to the production of bioenergy will be enhanced, so the use of non-woody biomass could be more and more relevant. Therefore, the future scenario of pelletization may change alongside the different kind of biomass available, thus a better understanding about the effects of using blends and binders to enhance the quality of pellet is fundamental. However, the whole binding mechanisms involved in the process result wide and difficult to be comprehended and properly managed. So far, very few efforts have been dedicated for the investigation of relationship between particle binding and pellet quality, which represents a gap in the literature demanding for study.

Remaining focused on the initial theme, there is a necessity to develop new mathematical models to assess the performance of pellets under different operating conditions. Currently, researchers found significant prediction model equations, but they are not dimensionally homogenous and cannot be generalized and used for further new materials or the production of new shapes of pellets. In line with this, proposing new significant empirical equations that describe any property of the pellet as a function of other features is an essential issue for pellets production improvement, especially if related to the original feedstock. This could be achieved by predicting functional relationships between the different physical and mechanical characteristics of pellets and the original raw materials, on the basis of the regression analysis of the experimental data.

Another emergent topic in tune with the relation between the pellet quality and its raw origin concerns the necessity to understand the influence of the diverse biomass feedstocks, mixed biomass with non-biodegradable wastes such as plastic, pre-treatment methods and the interaction of process parameters on the fuel pellet quality. Considering the potential markets of "biomass" as a substituent to wood and fossil fuels, future researches should be addressed to the assessment of fuel pellets quality and environmental impacts due to its production and use.

In accordance with this last point, and consistent with the other treated issues and concerns about biomass for energy use, the research should try to broaden the analyzes, increasingly focusing at life cycle scale, with the aim to include all the sustainability pillars as much as possible. This is one of the main objectives and challenges for researchers, called upon to clarify and understand how to approach to the stakeholders involved in the fuel biomass supply chain worldwide.

As highlighted in the other chapters, it would be considered useful and appropriate in the pellet qualification to add some indicators or indices linked to the sustainability of production, parameters that more and more often could make the difference to guide the choice of the global market or of the individual consumer.

Another aspect related to pellet qualification is a proper mechanical characterization. Studies on the compressive mechanical strength of pellets, and how this relates to bioenergy storage, transport, and related processes, are necessary. Low mechanical characteristics can affect pellet integrity during transport and handling, this could be key in ensuring a standardized product for processing. This minimizes transport costs and reduces the risk of fires through dust explosions.

\section{Conclusions}

This review focused on the most recent (2016-2020) scientific contributions regarding wood or agropellet quality. Only a few cases referred to papers published before 2016. The issue of good quality is fundamental for every biofuel and is probably even more important for pellets because of the large number of different possible feedstocks for pelletization.

It is possible to summarize the main findings of this review as follows:

1. Very few studies have investigated the relationship between different agroforest management systems and the quality of obtained pellets. This could be interesting focus for future research to give a better understanding of this topic. 
2. As reported in many other studies, including the most recent ones, wood pellets have a higher quality than agropellets, particularly in terms of their bulk density, ash content, heating value, and chemical composition.

3. However, agropellets are an interesting way to valorize agricultural waste-mostly for industrial use.

4. Blending and using binders are possible methods to improve pellet quality, but their use must be evaluated on a case-by-case basis.

5. There have been very interesting findings regarding the blending of woody biomass and microalgae, showing a consistent improvement in pellet quality.

6. Torrefaction seems to be the most investigated treatment to improve pellet quality, and recent studies tried to further improve such processes (ultrasonic torrefaction, pressurized steam torrefaction).

Author Contributions: Conceptualization, R.P. and F.L.; methodology, R.P., F.L., R.V.; formal analysis, F.L., W.S., A.S., D.T.; investigation, R.P., F.L.; resources, R.P., L.P.; data curation, F.L., W.S., A.S., R.V.; writing-original draft preparation, R.P., F.L., L.P.; writing-review and editing, R.P., F.L., R.V., L.P.; supervision, R.P., L.P.; funding acquisition, F.L., W.S., A.S., L.P. All authors have read and agreed to the published version of the manuscript.

Funding: The work was performed in the framework of the European project AGROinLOG "Demonstration of innovative integrated biomass logistics centers for the Agro-industry sector in Europe". This project has received funding from the European Union's Horizon 2020 research and innovation program under Grant Agreement No 727961.

Acknowledgments: This work was supported by the Italian Ministry for education and the University and Research (MIUR) for financial support (Law 232/2016, Italian University Departments of excellence)—UNITUS-DAFNE WP3.

Conflicts of Interest: The authors declare no conflict of interest. The funders had no role in the design of the study; in the collection, analyses, or interpretation of data; in the writing of the manuscript, or in the decision to publish the results.

\section{References}

1. Civitarese, V.; Acampora, A.; Sperandio, G.; Assirelli, A.; Picchio, R. Production of wood pellets from poplar trees managed as coppices with Different harvesting cycles. Energies 2019, 12, 2973-2988. [CrossRef]

2. Verma, V.K.; Bram, S.; De Ruyck, J. Small scale biomass heating systems: Standards, quality labelling and market driving factors-An EU outlook. Biomass Bioenergy 2009, 33, 1393-1402. [CrossRef]

3. Kaliyan, N.; Vance Morey, R. Factors affecting strength and durability of densified biomass products. Biomass Bioenergy 2009, 33, 337-359. [CrossRef]

4. Nunes, L.J.R.; Matias, J.C.O.; Catalão, J.P.S. Mixed biomass pellets for thermal energy production: A review of combustion models. Appl. Energy 2014, 127, 135-140. [CrossRef]

5. Puig-Arnavat, M.; Shang, L.; Sárossy, Z.; Ahrenfeldt, J.; Henriksen, U.B. From a single pellet press to a bench scale pellet mill-Pelletizing six different biomass feedstocks. Fuel Process. Technol. 2016, 142, 27-33. [CrossRef]

6. Rentizelas, A.A.; Tolis, A.J.; Tatsiopoulos, I.P. Logistics issues of biomass: The storage problem and the multi-biomass supply chain. Renew. Sustain. Energy Rev. 2009, 13, 887-894. [CrossRef]

7. Sánchez, J.; Curt, M.D.; Sanz, M.; Fernández, J. A proposal for pellet production from residual woody biomass in the island of Majorca (Spain). AIMS Energy 2015, 3, 480. [CrossRef]

8. Whittaker, C.; Shield, I. Factors affecting wood, energy grass and straw pellet durability-A review. Renew. Sustain. Energy Rev. 2017, 71, 1-11. [CrossRef]

9. Gilbert, P.; Ryu, C.; Sharifi, V.; Swithenbank, J. Effect of process parameters on pelletisation of herbaceous crops. Fuel 2009, 88, 1491-1497. [CrossRef]

10. Stasiak, M.; Molenda, M.; Bańda, M.; Wiącek, J.; Parafiniuk, P.; Gondek, E. Mechanical and combustion properties of sawdust-Straw pellets blended in different proportions. Fuel Process. Technol. 2017, 156, 366-375. [CrossRef]

11. Zhou, Y.; Zhang, Z.; Zhang, Y.; Wang, Y.; Yu, Y.; Ji, F.; Ahmad, R.; Dong, R. A comprehensive review on densified solid biofuel industry in China. Renew. Sustain. Energy Rev. 2016, 54, 1412-1428. [CrossRef] 
12. Kaliyan, N.; Morey, R.V. Natural binders and solid bridge type binding mechanisms in briquettes and pellets made from corn stover and switchgrass. Bioresour. Technol. 2010, 101, 1082-1090. [CrossRef] [PubMed]

13. Van der Stelt, M.J.C.; Gerhauser, H.; Kiel, J.H.A.; Ptasinski, K.J. Biomass upgrading by torrefaction for the production of biofuels: A review. Biomass Bioenergy 2011, 35, 3748-3762. [CrossRef]

14. Calderòn, C.; Colla, M.; Jossart, J.-M.; Hemeleers, N.; Cancian, G.; Aveni, N.; Caferri, C. Bioenergy Europe, Statistical report on pellet. In Proceedings of the European Biomass Conference and Exhibition, Stockholm Sweden, 12-15 June 2017.

15. Samuelsson, R.; Thyrel, M.; Sjöström, M.; Lestander, T.A. Effect of biomaterial characteristics on pelletizing properties and biofuel pellet quality. Fuel Process. Technol. 2009, 90, 1129-1134. [CrossRef]

16. Larsson, S.H.; Thyrel, M.; Geladi, P.; Lestander, T.A. High quality biofuel pellet production from pre-compacted low density raw materials. Bioresour. Technol. 2008, 99, 7176-7182. [CrossRef]

17. Lestander, T.A.; Finell, M.; Samuelsson, R.; Arshadi, M.; Thyrel, M. Industrial scale biofuel pellet production from blends of unbarked softwood and hardwood stems - the effects of raw material composition and moisture content on pellet quality. Fuel Process. Technol. 2012, 95, 73-77. [CrossRef]

18. Nizamuddin, S.; Mubarak, N.M.; Tiripathi, M.; Jayakumar, N.S.; Sahu, J.N.; Ganesan, P. Chemical, dielectric and structural characterization of optimized hydrochar produced from hydrothermal carbonization of palm shell. Fuel 2016, 163, 88-97. [CrossRef]

19. Toscano, G.; Riva, G.; Pedretti, E.F.; Corinaldesi, F.; Mengarelli, C.; Duca, D. Investigation on wood pellet quality and relationship between ash content and the most important chemical elements. Biomass Bioenergy 2013, 56, 317-322. [CrossRef]

20. Ahn, B.J.; Chang, H.; Lee, S.M.; Choi, D.H.; Cho, S.T.; Han, G.; Yang, I. Effect of binders on the durability of wood pellets fabricated from Larix kaemferi C. and Liriodendron tulipifera L. sawdust. Renew. Energy 2014, 62, 18-23. [CrossRef]

21. Križan, P.; Matú, M.; Šooš, L'.; Beniak, J. Behavior of beech sawdust during densification into a solid biofuel. Energies 2015, 8, 6382-6398.

22. Stelte, W.; Sanadi, A.R.; Shang, L.; Holm, J.K.; Ahrenfeldt, J.; Henriksen, U.B. Recent developments in biomass pelletization-A review. BioResources 2012, 7, 4451-4490.

23. Picchio, R.; Spina, R.; Sirna, A.; Monaco, A.L.; Civitarese, V.; Giudice, A.D.; Suardi, A.; Pari, L. Characterization of woodchips for energy from forestry and agroforestry production. Energies 2012, 5, 3803-3816. [CrossRef]

24. Mostafa, M.E.; Hu, S.; Wang, Y.; Su, S.; Hu, X.; Elsayed, S.A.; Xiang, J. The significance of pelletization operating conditions: An analysis of physical and mechanical characteristics as well as energy consumption of biomass pellets. Renew. Sustain. Energy Rev. 2019, 105, 332-348. [CrossRef]

25. Tenorio, C.; Moya, R.; Valaert, J. Characterisation of pellets made from oil palm residues in Costa Rica. J. Oil Palm Res. 2016, 28, 198-210. [CrossRef]

26. Li, H.; Jiang, L.-B.; Li, C.-Z.; Liang, J.; Yuan, X.-Z.; Xiao, Z.-H.; Xiao, Z.-H.; Wang, H. Co-pelletization of sewage sludge and biomass: The energy input and properties of pellets. Fuel Process. Technol. 2015, 132, 55-61. [CrossRef]

27. Cheng, J.; Zhou, F.; Si, T.; Zhou, J.; Cen, K. Mechanical strength and combustion properties of biomass pellets prepared with coal tar residue as a binder. Fuel Process. Technol. 2018, 179, 229-237. [CrossRef]

28. Kijo-Kleczkowska, A.; Środa, K.; Kosowska-Golachowska, M.; Musiał, T.; Wolski, K. Combustion of pelleted sewage sludge with reference to coal and biomass. Fuel 2016, 170, 141-160. [CrossRef]

29. Azargohar, R.; Nanda, S.; Dalai, A.K. Densification of agricultural wastes and forest residues: A review on influential parameters and treatments. Recent Adv. Biofuels Bioenergy Util. 2018, 27-51. [CrossRef]

30. Kumar, P.; Barrett, D.M.; Delwiche, M.J.; Stroeve, P. Methods for pretreatment of lignocellulosic biomass for efficient hydrolysis and biofuel production. Ind. Eng. Chem. Res. 2009, 48, 3713-3729. [CrossRef]

31. Ramos, L.P. The chemistry involved in the steam treatment of lignocellulosic materials. Quim. Nova 2003, 26, 863-871. [CrossRef]

32. Sun, Y.; Cheng, J. Hydrolysis of lignocellulosic materials for ethanol production: A review. Bioresour. Technol. 2002, 83, 1-11. [CrossRef]

33. Stelte, W.; Holm, J.K.; Sanadi, A.R.; Barsberg, S.; Ahrenfeldt, J.; Henriksen, U.B. Fuel pellets from biomass: The importance of the pelletizing pressure and its dependency on the processing conditions. Fuel 2011, 90, 3285-3290. [CrossRef] 
34. Mei, Y.; Liu, R.; Yang, Q.; Yang, H.; Shao, J.; Draper, C.; Zhang, S.; Chen, H. Torrefaction of cedarwood in a pilot scale rotary kiln and the influence of industrial flue gas. Bioresour. Technol. 2015, 177, 355-360. [CrossRef] [PubMed]

35. Li, H.; Liu, X.; Legros, R.; Bi, X.T.; Lim, C.J.; Sokhansanj, S. Pelletization of torrefied sawdust and properties of torrefied pellets. Appl. Energy 2012, 93, 680-685. [CrossRef]

36. Kumar, L.; Koukoulas, A.A.; Mani, S.; Satyavolu, J. Integrating torrefaction in the wood pellet industry: A critical review. Energy Fuels 2017, 31, 37-54. [CrossRef]

37. Picchio, R.; Proto, A.R.; Civitarese, V.; Di Marzio, N.; Latterini, F. Recent Contributions of Some Fields of the Electronics in Development of Forest Operations Technologies. Electronics 2019, 8, 1465. [CrossRef]

38. García-Maraver, A.; Popov, V.; Zamorano, M. A review of European standards for pellet quality. Renew. Energy 2011, 36, 3537-3540. [CrossRef]

39. Alakangas, E. Solid biofuels for energy: A lower greenhouse gas alternative. Green Energy Technol. 2014, 28, 1-3.

40. Rhén, C.; Gref, R.; Sjöström, M.; Wästerlund, I. Effects of raw material moisture content, densification pressure and temperature on some properties of Norway spruce pellets. Fuel Process. Technol. 2005, 87, 11-16. [CrossRef]

41. Masche, M.; Puig-Arnavat, M.; Jensen, P.A.; Holm, J.K.; Clausen, S.; Ahrenfeldt, J.; Henriksen, U.B. From wood chips to pellets to milled pellets: The mechanical processing pathway of Austrian pine and European beech. Powder Technol. 2019, 350, 134-145. [CrossRef]

42. Monedero, E.; Portero, H.; Lapuerta, M. Combustion of poplar and pine pellet blends in a $50 \mathrm{kw}$ domestic boiler: Emissions and combustion efficiency. Energies 2018, 11, 1580. [CrossRef]

43. Santos, L.B.; Striebeck, M.V.; Crespi, M.S.; Capela, J.M.V.; Ribeiro, C.A.; De Julio, M. Energy evaluation of biochar obtained from the pyrolysis of pine pellets. J. Anal. Calorim. 2016, 126, 1879-1887. [CrossRef]

44. Liu, Z.; Jiang, Z.; Fei, B.; Cai, Z.; Liu, X. Comparative properties of bamboo and pine pellets. Wood Fiber Sci. 2014, 46, 510-518.

45. Rabaçal, M.; Fernandes, U.; Costa, M. Combustion and emission characteristics of a domestic boiler fired with pellets of pine, industrial wood wastes and peach stones. Renew. Energy 2013, 51, 220-226. [CrossRef]

46. Stelte, W.; Clemons, C.; Holm, J.K.; Sanadi, A.R.; Ahrenfeldt, J.; Shang, L.; Henriksen, U.B. Pelletizing properties of torrefied spruce. Biomass Bioenergy 2011, 35, 4690-4698. [CrossRef]

47. Brackley, A.M.; Parrent, D.J. Production of wood pellets from Alaska-grown white spruce and hemlock. Usda. Serv. 2011. [CrossRef]

48. Savelli, S.; Cavalli, R.; Baldini, S.; Picchio, R. Small scale mechanization of thinning in artificial coniferous plantation. Croat. J. Eng. 2010, 31, 11-21.

49. Lerma-Arce, V.; Oliver-Villanueva, J.V.; Segura-Orenga, G. Influence of raw material composition of Mediterranean pinewood on pellet quality. Biomass Bioenergy 2017, 99, 90-96. [CrossRef]

50. Agar, D.A.; Rudolfsson, M.; Kalén, G.; Campargue, M.; Da Silva Perez, D.; Larsson, S.H. A systematic study of ring-die pellet production from forest and agricultural biomass. Fuel Process. Technol. 2018, 180, 47-55. [CrossRef]

51. Picchio, R.; Spina, R.; Calienno, L.; Venanzi, R.; Lo Monaco, A. Forest operations for implementing silvicultural treatments for multiple purposes. Ital. J. Agron. 2016, 11, 156-161.

52. Gündüz, G.; Saraçoğlu, N.; Aydemir, D. Characterization and elemental analysis of wood pellets obtained from low-valued types of wood. Energy Sources 2016, 38, 2211-2216. [CrossRef]

53. Zawiślak, K.; Sobczak, P.; Kraszkiewicz, A.; Niedziółka, I.; Parafiniuk, S.; Kuna-Broniowska, I.; Tanaś, W.; Żukiewicz-Sobczak, W.; Obidziński, S. The use of lignocellulosic waste in the production of pellets for energy purposes. Renew. Energy 2020, 145, 997-1003. [CrossRef]

54. Artemio, C.P.; Maginot, N.H.; Serafín, C.U.; Rahim, F.P.; Guadalupe, R.Q.J.; Fermín, C.M. Physical, mechanical and energy characterization of wood pellets obtained from three common tropical species. PeerJ 2018, 2018, 1-16. [CrossRef] [PubMed]

55. Bados, R.; Esteban, L.S.; Pérez, P.; Mediavilla, I.; Fernández, M.J.; Barro, R.; Corredor, R.; Carrasco, J.E. Study of the production of pelletized biofuels from Mediterranean scrub biomass. In Proceedings of the European Biomass Conference and Exhibition, Stockholm Sweden, 12-15 June 2017. 
56. Aragón-Garita, S.; Moya, R.; Bond, B.; Valaert, J.; Tomazello Filho, M. Production and quality analysis of pellets manufactured from five potential energy crops in the Northern Region of Costa Rica. Biomass Bioenergy 2016, 87, 84-95. [CrossRef]

57. Ramírez, V.; Martí-Herrero, J.; Romero, M.; Rivadeneira, D. Energy use of Jatropha oil extraction wastes: Pellets from biochar and Jatropha shell blends. J. Clean. Prod. 2019, 215, 1095-1102. [CrossRef]

58. Romuli, S.; Karaj, S.; Correa, C.R.; Kruse, A.; Müller, J. Physico-mechanical properties and thermal decomposition characteristics of pellets from Jatropha curcas L. residues as affected by water addition. Biofuels 2019, 1-8. [CrossRef]

59. Alarcon, M.; Santos, C.; Cevallos, M.; Eyzaguirre, R.; Ponce, S. Study of the Mechanical and Energetic Properties of Pellets Produce from Agricultural Biomass of Quinoa, Beans, Oat, Cattail and Wheat. Waste Biomass Valori 2017, 8, 2881-2888. [CrossRef]

60. Burg, P.; Masan, V.; Ludin, D. Possibilities of using grape marc for making fuel pellets. Eng. Rural Dev. 2017, 16, 1333-1338.

61. Stelte, W.; Barsberg, S.T.; Clemons, C.; Morais, J.P.S.; de Freitas Rosa, M.; Sanadi, A.R. Coir Fibers as Valuable Raw Material for Biofuel Pellet Production. Waste Biomass Valori 2019, 10, 3535-3543. [CrossRef]

62. Royo, J.; Canalís, P.; Quintana, D.; Díaz-Ramírez, M.; Sin, A.; Rezeau, A. Experimental study on the ash behaviour in combustion of pelletized residual agricultural biomass. Fuel 2019, 239, 991-1000. [CrossRef]

63. Marrugo, G.; Valdés, C.F.; Gómez, C.; Chejne, F. Pelletizing of Colombian agro-industrial biomasses with crude glycerol. Renew. Energy 2019, 134, 558-568. [CrossRef]

64. Yang, I.; Kim, S.-H.; Sagong, M.; Han, G.S. Fuel characteristics of agropellets fabricated with rice straw and husk. KoreanJ. Chem. Eng. 2016, 33, 851-857. [CrossRef]

65. Ríos-Badrán, I.M.; Luzardo-Ocampo, I.; García-Trejo, J.F.; Santos-Cruz, J.; Gutiérrez-Antonio, C. Production and characterization of fuel pellets from rice husk and wheat straw. Renew. Energy 2020, 145, $500-507$. [CrossRef]

66. Park, S.; Kim, S.J.; Oh, K.C.; Cho, L.; Kim, M.J.; Jeong, I.S.; Lee, C.G.; Kim, D.H. Investigation of agro-byproduct pellet properties and improvement in pellet quality through mixing. Energy 2019, 190, 116380. [CrossRef]

67. Djatkov, D.; Martinov, M.; Kaltschmitt, M. Influencing parameters on mechanical-physical properties of pellet fuel made from corn harvest residues. Biomass Bioenergy 2018, 119, 418-428. [CrossRef]

68. Miranda, M.T.; Sepúlveda, F.J.; Arranz, J.I.; Montero, I.; Rojas, C.V. Physical-energy characterization of microalgae Scenedesmus and experimental pellets. Fuel 2018, 226, 121-126. [CrossRef]

69. Wattana, W.; Phetklung, S.; Jakaew, W.; Chumuthai, S.; Sriam, P.; Chanurai, N. Characterization of Mixed Biomass Pellet Made from Oil Palm and Para-rubber Tree Residues. Energy Procedia 2017, 138, 1128-1133. [CrossRef]

70. Brunerová, A.; Müller, M.; Šleger, V.; Ambarita, H.; Valášek, P. Bio-pellet fuel from oil palm empty fruit bunches (EFB): Using European standards for quality testing. Sustainability 2018, 10, 4443.

71. Jeguirim, M.; Limousy, L.; Fossard, E. Characterization of coffee residues pellets and their performance in a residential combustor. Int. J. Green Energy 2016, 13, 608-615. [CrossRef]

72. Fernández-Puratich, H.; Hernández, D.; Lerma Arce, V. Characterization and cost savings of pellets fabricated from Zea mays waste from corn mills combined with Pinus radiata. Renew. Energy 2017, 114, 448-454. [CrossRef]

73. Toscano, G.; Alfano, V.; Scarfone, A.; Pari, L. Pelleting vineyard pruning at low cost with a mobile technology. Energies 2018, 11, 2477. [CrossRef]

74. Brand, M.A.; Jacinto, R.C. Apple pruning residues: Potential for burning in boiler systems and pellet production. Renew. Energy 2020, 152, 458-466. [CrossRef]

75. Suardi, A.; Latterini, F.; Alfano, V.; Palmieri, N.; Bergonzli, S.; Pari, L. Analysis of the Work Productivity and Costs of a Stationary Chipper Applied to the Harvesting of Olive Tree Pruning for Bio-Energy Production. Energies 2020, 13, 1359. [CrossRef]

76. Suardi, A.; Latterini, F.; Alfano, V.; Palmieri, N.; Bergonzoli, S.; Karampinis, E.; Kougioumtzis, M.A.; Grammelis, P.; Pari, L. Machine Performance and Hog Fuel Quality Evaluation in Olive Tree Pruning Harvesting Conducted Using a Towed Shredder on Flat and Hilly Fields. Energies 2020, 13, 1713-1728. [CrossRef]

77. Pradhan, P.; Mahajani, S.M.; Arora, A. Production and utilization of fuel pellets from biomass: A review. Fuel Process. Technol. 2018, 181, 215-232. [CrossRef] 
78. Scatolino, M.V.; Neto, L.F.C.; Protásio, T.P.; Carneiro, A.C.O.; Andrade, C.R.; Guimarães Júnior, J.B.; Mendes, L.M. Options for Generation of Sustainable Energy: Production of Pellets Based on Combinations Between Lignocellulosic Biomasses. Waste Biomass Valori 2018, 9, 479-489. [CrossRef]

79. Dołzyńska, M.; Obidziński, S.; Kowczyk-Sadowy, M.; Krasowska, M. Densification and combustion of cherry stones. Energies 2019, 12,1-15. [CrossRef]

80. González, W.A.; López, D.; Pérez, J.F. Biofuel quality analysis of fallen leaf pellets: Effect of moisture and glycerol contents as binders. Renew. Energy 2020, 147, 1139-1150. [CrossRef]

81. Peng, J.; Bi, X.T.; Lim, C.J.; Peng, H.; Kim, C.S.; Jia, D.; Zuo, H. Sawdust as an effective binder for making torrefied pellets. Appl. Energy 2015, 157, 491-498. [CrossRef]

82. Harun, N.Y.; Parvez, A.M.; Afzal, M.T. Process and energy analysis of pelleting agricultural and woody biomass blends. Sustainability 2018, 10, 1-9.

83. Liu, Z.; Mi, B.; Jiang, Z.; Fei, B.; Cai, Z.; Liu, X. Improved bulk density of bamboo pellets as biomass for energy production. Renew. Energy 2016, 86, 1-7. [CrossRef]

84. García, R.; Gil, M.V.; Rubiera, F.; Pevida, C. Pelletization of wood and alternative residual biomass blends for producing industrial quality pellets. Fuel 2019, 251, 739-753. [CrossRef]

85. Platace, R.; Adamovics, A.; Kalnacs, J. Engineering for Rural Development Production of Reed Canary Grass-Wood Pellets. Eng. Rural Dev. 2016, 371-374.

86. Barbanera, M.; Lascaro, E.; Stanzione, V.; Esposito, A.; Altieri, R.; Bufacchi, M. Characterization of pellets from mixing olive pomace and olive tree pruning. Renew. Energy 2016, 88, 185-191. [CrossRef]

87. Hosseinizand, H.; Sokhansanj, S.; Lim, C.J. Co-pelletization of microalgae Chlorella vulgaris and pine sawdust to produce solid fuels. Fuel Process. Technol. 2018, 177, 129-139. [CrossRef]

88. Cui, X.; Yang, J.; Shi, X.; Lei, W.; Huang, T.; Bai, C. Experimental investigation on the energy consumption, physical, and thermal properties of a novel pellet fuel made from wood residues with microalgae as a binder. Energies 2019, 12, 3425. [CrossRef]

89. Wang, Y.; Wu, K.; Sun, Y. Pelletizing Properties of Wheat Straw Blending with Rice Straw. Energy Fuels 2017, 31, 5126-5134. [CrossRef]

90. Lisowski, A.; Matkowski, P.; Dąbrowska, M.; Piątek, M.; Świętochowski, A.; Klonowski, J.; Mieszkalski, L.; Reshetiuk, V. Particle Size Distribution and Physicochemical Properties of Pellets Made of Straw, Hay, and Their Blends. Waste Biomass Valori 2018, 11, 63-75. [CrossRef]

91. Jiang, L.; Yuan, X.; Xiao, Z.; Liang, J.; Li, H.; Cao, L.; Wang, H.; Chen, X.; Zeng, G. A comparative study of biomass pellet and biomass-sludge mixed pellet: Energy input and pellet properties. Energy Convers. Manag. 2016, 126, 509-515. [CrossRef]

92. Abedi, A.; Dalai, A.K. Study on the quality of oat hull fuel pellets using bio-additives. Biomass Bioenergy 2017, 106, 166-175. [CrossRef]

93. Abedi, A.; Cheng, H.; Dalai, A.K. Effects of Natural Additives on the Properties of Sawdust Fuel Pellets. Energy Fuels 2018, 32, 1863-1873. [CrossRef]

94. Zhang, T.; Qiu, L.; Wang, Y.; Zhang, C.; Kang, K. Comparison of Bio-Oil and Waste Cooking Oil as Binders during the Codensification of Biomass: Analysis of the Pellet Quality. Bioenergy Res. 2019, 12, 558-569. [CrossRef]

95. Obidziński, S.; Piekut, J.; Dec, D. The influence of potato pulp content on the properties of pellets from buckwheat hulls. Renew. Energy 2016, 87, 289-297. [CrossRef]

96. Obidziński, S.; Dołżyńska, M.; Kowczyk-Sadowy, M.; Jadwisieńczak, K.; Sobczak, P. Densification and Fuel Properties of Onion Husks. Energies 2019, 12, 4687.

97. Gageanu, I.; Cujbescu, D.; Persu, C.; Voicu, G. Impact of using additives on quality of agricultural biomass pellets. Eng. Rural Dev. 2018, 17, 1632-1638.

98. Gageanu, I.; Persu, C.; Cujbescu, D.; Gheorghe, G.; Voicu, G. Influence of using additives on quality of pelletized fodder. Eng. Rural Dev. 2019, 18, 362-367.

99. Mišljenović, N.; Čolović, R.; Vukmirović, D.; Brlek, T.; Bringas, C.S. The effects of sugar beet molasses on wheat straw pelleting and pellet quality. A comparative study of pelleting by using a single pellet press and a pilot-scale pellet press. Fuel Process. Technol. 2016, 144, 220-229.

100. Jamradloedluk, J.; Lertsatitthanakorn, C. Influences of Mixing Ratios and Binder Types on Properties of Biomass Pellets. Energy Procedia 2017, 138, 1147-1152. [CrossRef] 
101. Si, Y.; Hu, J.; Wang, X.; Yang, H.; Chen, Y.; Shao, J.; Chen, H. Effect of Carboxymethyl Cellulose Binder on the Quality of Biomass Pellets. Energy Fuels 2016, 30, 5799-5808. [CrossRef]

102. Dabrowska-Salwin, M.; Lisowski, A.; Kostrubiec, M.; Swietochowski, A. Pressure agglomeration of biomass with addition of calcium carbonate. Eng. Rural Dev. 2016, 542-546.

103. Iftikhar, M.; Asghar, A.; Ramzan, N.; Sajjadi, B.; Chen, W. Biomass densification: Effect of cow dung on the physicochemical properties of wheat straw and rice husk based biomass pellets. Biomass Bioenergy 2019, 122, 1-16. [CrossRef]

104. Gehrig, M.; Wöhler, M.; Pelz, S.; Steinbrink, J.; Thorwarth, H. Kaolin as additive in wood pellet combustion with several mixtures of spruce and short-rotation-coppice willow and its influence on emissions and ashes. Fuel 2019, 235, 610-616. [CrossRef]

105. García, R.; González-Vázquez, M.P.; Martín, A.J.; Pevida, C.; Rubiera, F. Pelletization of torrefied biomass with solid and liquid bio-additives. Renew. Energy 2020, 151, 175-183. [CrossRef]

106. Tang, Y.; Chandra, R.P.; Sokhansanj, S.; Saddler, J.N. The Role of Biomass Composition and Steam Treatment on Durability of Pellets. Bioenergy Res. 2018, 11, 341-350. [CrossRef]

107. Pirraglia, A.; Gonzalez, R.; Saloni, D.; Denig, J. Technical and economic assessment for the production of torrefied ligno-cellulosic biomass pellets in the US. Energy Convers. Manag. 2013, 66, 153-164. [CrossRef]

108. Kizuka, R.; Ishii, K.; Sato, M.; Fujiyama, A. Characteristics of wood pellets mixed with torrefied rice straw as a biomass fuel. Int. J. Energy Env. Eng. 2019, 10, 357-365. [CrossRef]

109. Gaitán-Alvarez, J.; Moya, R.; Puente-Urbina, A.; Rodriguez-Zuñiga, A. Physical and compression properties of pellets manufactured with the biomass of five woody tropical species of Costa Rica torrefied at different temperatures and times. Energies 2017, 10, 1205. [CrossRef]

110. Azócar, L.; Hermosilla, N.; Gay, A.; Rocha, S.; Díaz, J.; Jara, P. Brown pellet production using wheat straw from southern cities in Chile. Fuel 2019, 237, 823-832. [CrossRef]

111. Puy, N.; Alier, S.; Bartrolí, J. Production of torrefied pellets from agroforestry biomass for local and regional use. In Proceedings of the 24th European Biomass Conference and Exhibition, Amsterdam, The Netherlands, 6-9 June 2016.

112. Manouchehrinejad, M.; Mani, S. Torrefaction after pelletization (TAP): Analysis of torrefied pellet quality and co-products. Biomass Bioenergy 2018, 118, 93-104. [CrossRef]

113. Song, X.; Yang, Y.; Zhang, M.; Zhang, K.; Wang, D. Ultrasonic pelleting of torrefied lignocellulosic biomass for bioenergy production. Renew. Energy 2018, 129, 56-62. [CrossRef]

114. Kudo, S.; Okada, J.; Ikeda, S.; Yoshida, T.; Asano, S.; Hayashi, J.I. Improvement of Pelletability of Woody Biomass by Torrefaction under Pressurized Steam. Energy Fuels 2019, 33, 11253-11262. [CrossRef]

115. Gong, S.H.; Im, H.S.; Um, M.; Lee, H.W.; Lee, J.W. Enhancement of waste biomass fuel properties by sequential leaching and wet torrefaction. Fuel 2019, 239, 693-700. [CrossRef]

116. Rejdak, M.; Czardybon, A.; Ignasiak, K.; Robak, J. Utilization of waste forest biomass: Pelletization studies of torrefied sawmill wood chips. In Proceedings of the 11th Conference on Interdisciplinary Problems in Environmental Protection and Engineering EKO-DOK 2019, Polanica-Zdroj, Poland, 8-10 April 2019; E3S Web Conferences: Les Ulis, France, 2019; Volume 100.

117. Shahrukh, H.; Oyedun, A.O.; Kumar, A.; Ghiasi, B.; Kumar, L.; Sokhansanj, S. Techno-economic assessment of pellets produced from steam pretreated biomass feedstock. Biomass Bioenergy 2016, 87, 131-143. [CrossRef]

118. Obernberger, I.; Thek, G. The Pellet Handbook: The Production and Thermal Utilisation of Pellets; Routledge: Abingdon, UK, 2010; ISBN 1844076318.

119. Mobini, M.; Sowlati, T.; Sokhansanj, S. A simulation model for the design and analysis of wood pellet supply chains. Appl. Energy 2013, 111, 1239-1249. [CrossRef]

120. Mobini Dehkordi, M.M. On the design and analysis of forest biomass to biofuel and bioenergy supply chains. Ph.D. Thesis, University of British Columbia, Vancouver, BC, Canada, April 2015.

121. Trømborg, E.; Ranta, T.; Schweinle, J.; Solberg, B.; Skjevrak, G.; Tiffany, D.G. Economic sustainability for wood pellets production-A comparative study between Finland, Germany, Norway, Sweden and the US. Biomass Bioenergy 2013, 57, 68-77. [CrossRef]

122. Koppejan, J.; Sokhansanj, S.; Melin, S.; Madrali, S. Status overview of torrefaction technologies. IEA Bioenergy Task 2012, 32, 1-54.

123. Radics, R.I.; Gonzalez, R.; Bilek, E.T.M.; Kelley, S.S. Systematic review of torrefied wood economics. BioResources 2017, 12, 6868-6884. [CrossRef] 
124. Beets, M. A Torrefied Wood Pellet Supply Chain. A detailed cost analysis of the comptetitiveness of torrefied wood pellets compared to white wood pellets. Master's Thesis, Utrecht University, Utrecht, The Netherlands, 2017.

125. Yun, H.; Clift, R.; Bi, X. Process simulation, techno-economic evaluation and market analysis of supply chains for torrefied wood pellets from British Columbia: Impacts of plant configuration and distance to market. Renew. Sustain. Energy Rev. 2020, 127, 109745. [CrossRef] 